\begin{tabular}{ll}
\hline POLITEIA/ POLITEIA: Jurnal Ilmu Politik \\
Politeia, 14 (1) (2022): 1-16 \\
ISSN (Print), ISSN (Online) \\
Available online https://jurnal.usu.ac.id/index.php/politeia
\end{tabular}

\title{
Faktor-Faktor Penyebab Kegagalan Gerakan Pemberontakan Partai Komunis Indonesia (PKI) 1926-1927
}

\author{
Nami Irawan Batubara*
}

Program Studi Ilmu Politik, Universitas Syiah Kuala, Banda Aceh, Indonesia, 23111

Submitted : 17 Oktober 2021 Revision : 18 Desember 2021 Accepted : 10 Januari 2022

\begin{abstract}
Abstrak
Tantangan dunia pertahanan dan keamanan selalu bersifat dinamis, selalu mengalami perubahan baik bentuk, sifat, maupun sumber dari ancaman itu sendiri. Pada era sebelumnya tantangan pertahanan keamanan masih berupa penyerangan langsung dengan peralatan perang dan melibatkan kontak fisik yang lebih intens, sementara di era teknologi dan informasi yang berkembang cepat tantangan keamanan dan pertahanan memunculkan satu dimensi baru yaitu keamanan siber. Artikel ini akan menggambarkan bagaimana ancaman dan serangan siber itu menjadi tantangan bagi dunia pertahanan di era sekarang dan bagaimana perkembangan sistem pertahanan dan keamanan siber yang dimiliki oleh Indonesia saat ini

Kata Kunci: Pertahanan, Keamanan, Teknologi dan Informasi, Siber.

Abstrak

The challenges in the world of defense and security are always dynamic, always changing in form, nature, and source of the threat itself. In the previous era, the challenges of defense and security were form by direct attacks with war equipment and involving more intense physical contact, while in the era of technology and information which is developing rapidly, security and defense challenges have created a new dimension, namely cyber security. This article will describe how cyber threats and attacks are a challenge for the world of defense in this current era, and how is the development of Indonesia's current cyber defense and security system.
\end{abstract}

Keyword: Defence, Security, technology and information, Cyber.

How to Cite: Rizki, M. (2021). Perkembangan Sistem Pertahanan/ Keamanan Siber Indonesia dalam Menghadapi Tantangan Perkembangan Teknologi dan Informasi. Politeia : Jurnal Ilmu Politik, 14 (1): 1-16.

*Corresponding author:

E-mail: rizkimaqbul@gmail.com 
PENDAHULUAN

Sejak tahun 1900 hingga proklamasi kemerdekaan Indonesia tahun 1945, perjuangan para pahlawan kemerdekaan Indonesia telah menggunakan pendekatan yang berbeda. Para pejuang kemerdekaan mulai menggunakan pendekatan baru yang menandai kebangkitan dari gerakan politik bumiputera.Misalnya gerakan rakyat yang tampil dalam bentuk-bentuk seperti suratkabar dan jurnal, rapat dan pertemuan, serikat buruh dan pemogokan, organisasi dan partai, novel, nyanyian, teater, dan pemberontakan. Para tokoh pergerakan mulai menyadari pentingnya mendirikan organisasi-organisasi guna menghimpun dan memobilisasi masa untuk melawan penindasan yang dilakukan oleh pemerintahan kolonialmelalui instrumen gerakan sosial.

Gerakan sosial menurut Jary adalah suatu aliansi sosial yang terdiri dari sejumlah besar orang yang berserikat untuk mendorong ataupun menghambat aspek perubahan dalam suatu masyarakat (Sunarto, 2004: 195). Klandersman membuat perumusan serupa dengan mengutip pendapat Tarrow yang menyatakan bahwa gerakan sosial adalah pertentangan atau perlawanan kolektif yang dilakukan oleh orang-orang yang memiliki solidaritas dan tujuan yang sama di dalam proses interaksi yang berkesinambungan dengan pihak elite, pihak lawan, atau pihak yang berwenang (Quah dan Sales, 2000: 236).Gerakan sosial adalah bentuk ekspresi masyarakat yang bertujuan menuntut kesetaraan dan keadilan sosial, serta mengambarkan perjuangan-perjuangan masyarakat dalam membela identitas dan warisanwarisan kultural mereka (Singh dalam Sukmana, 2010: 20-21).

Pada masa kebangkitan gerakan sosialdi Indonesia, terdapatbeberapa serikat atau organisasi yang mewadahi tokoh-tokoh pejuang kemerdekaan. Misalnya Sarekat Islam (SI), NationalIndische Partij (NIP),Indische SociaalDemocratische Vereeniging (ISDV), Partai Komunis Indonesia (PKI), Insulide,SarekatRakjat, dan lain sebagainya.Partai Komunis Indonesia (PKI) merupakan salah satu kekuatan progresif yang memiliki perandalammemerdekakan bangsa Indonesia. Meskipun saat ini PKI merupakan organisasi yang dilarang eksistensi maupun pemikirannya di Indonesia.

\begin{tabular}{lll}
\multicolumn{2}{c}{ Keputusan } & pelarangan \\
pendirian partai & yang & berasaskan \\
sosialis-komunis & serta & pemikiran-
\end{tabular} pemikirannya tercantum dalam TAP MPRS Nomor XXV/MPRS/1966 tentang Larangan Ajaran Komunisme/Marxisme. Pelarangan ini merupakan akibat dari pemberontakan yang melibatkan pimpinan Partai Komunis Indonesia (PKI) terhadap pemerintah Indonesia pada tahun 1965 dulu.Secara historis pemikiran sosialiskomunis diperkenalkan pertama kali di Indonesia oleh seorang kewarganegaraan Belanda yaitu HenkSneevliet pada tahun 1913 (Syukur, 2008: 1). Gagasan komunisme berpangkal dari pemikiran seorang ilmuwan Jerman Karl Heinrich Marx yang hidup pada abad ke-19 (18181883).Ide ini lahir karena situasi buruk yang dialami oleh kaum buruh di Eropa Barat saat itu, seperti upah rendah, jam kerja yang panjang, penyalahgunaan tenaga perempuan 
dan anak, serta pabrik-pabrik yang membahayakan dan mengganggu kesehatan(Mariam, 2005: 139).

Situasi buruk tersebut kemudian dijadikan sebagai alasan bagi cendekiawan-cendekiwan seperti Robert Owen dari Inggris (1771-1858), Saint Simon (1760-1825), dan Fourier di Prancis untuk mencari jalan keluarnya (Mariam, 2005: 139). Namun cendikiawan-cendikiawan tersebut hanya terdorong pada rasa prikemanusiaan tanpa disertai tindakan-tindakan ataupun konsepsi yang nyata tentang tujuan dan strategi untuk mengatasi masalah tersebut, sehingga mereka sering dikenal sebagai kaum sosialis utopia(Ahmad, 2017: 32).Oleh sebab itu, Marx kemudian memberikan suatu konsep baru yang disebut sebagai sosialisme ilmiah (Mariam, 2005: 140).Marx berangkat dari konsepsi Hegel tentang dialektika namun dengan melakukan modifikasi, jika Hegel berpendapat bahwa semua hal hanyalah gambaran yang direalisasikan oleh ide yang eksis dan kekal sebelum adanya dunia,dan akan terus bergerak dalam lingkaran yang mengulang (bersifat final/absolut), sedangkan Marx menggunakan metode pembedahan sejarah secara materialis, yakni suatu metode yang menjelaskan pengetahuan manusia melalui keberadaannya, dan bukan kebalikkannya (Engels terjemahan Sprague, 2016).

Konsepsi kaum idealis (Hegel, dkk) tidak mengenal perjuangan kelas berdasarkan kepentingan ekonomi, baginya semua sistem produksi dan relasi ekonomi tidak lebih dari fenomena yang hanya terjadi dalam beberapa kesempatan (tidak tetap) dan subordinat dalam sejarah. Sementara Marx memandang semua sejarah masa lalu (kecuali primitif) adalah sejarah perjuangan kelas, bahwa seluruh kelaskelas yang bertentangan selalu berupa produk dari kondisi-kondisi ekonomi zamannya; bahwa struktur ekonomi dalam sebuah masyarakat selalu menjadi landasan yang riil dari masyarakat tersebut, sekaligus hanya struktur ekonomi itulah yang dapat menyusun penjelasan tentang bangunan-atas (superstruktur) lembaga-lembaga hukum dan politik, gagasan-gagasan religius, filsafat, dan lainnya yang berada pada riwayat perjuangan sejarah tertentu (Engels terjemahan Sprague, 2016). Dengan demikian gagasan sosialisme Marx berubah menjadi ilmiah, karena menemukan konsepsi materialis mengenai sejarah (materialis-historis) dan penyingkapan produksi kapitalis (pemilik kapital/alat-alat produksi) melalui eksploitasi nilai-lebih yaitu sebuah produksi sosial yangdihasilkan oleh kelas pekerja namun diambil oleh kelas berkuasa (borjuis/pemilik modal) (Ernest terjemahan Nastor, 2006).

Bagi Marx masyarakat tidak dapat diperbaiki melalui tambal sulam dan harus dirubah secara radikal melalui penghancuran-penghancuran pada setiap sendi-sendi struktur kapitalis. Dengan demikian, istilah "komunisme" digunakan oleh aliran sosialis yang lebih radikal yang menuntut penghapusan secara total segala hak kepemilikan pribadi dan mencita-citakan kesamaan konsumsi dengan mengharapkan keadaan komunis (masyarakat tanpa kelas/setara), dan tidak mengharapkan pemberian/kebaikan pemerintah, melainkan karena perjuangan kaum terhisap (proletar/buruh) itu sendiri melalui jalan revolusi (Ahmad, 2017: 33). 
Dalam perkembangannya, tokoh marxisme dari Rusia yaitu Lenin menginterpretasikan lagi gagasan Marx, bahwa proses sejarah dapat dipercepat (Saleh, et al., 2009: 7). Artinya bahwa terbentukny 7). masyarakat tanpa kelas dapat dipercepat melalui instrumen Partai Komunis yang mewakili kelompok proletar. Berbeda dengan pandangan Marx yang mengangap bahwa masyarakat komunis hanya bisa diibaratkan dengan jatuhnya buah yang sudah matang dari pohon (Saleh, et al., 2009: 7). Artinya revolusi akan sendirinya terjadi di suatu negara yang tingkat kapitalismenya sudah maju atau krisis. Namun Lenin berkeyakinan bahwa buah itu harus direbut oleh kelas proletar yang terhimpun dalam Partai Komunis.Dalam hal ini, Sneevliet hendak menyebarkan dan menerapkan konsepini di Nusantara dengan cara membentuk serikat dan mencetak kader-kader marxisme sebagai pelopor kelas proletar.

Namun belum sempat mempelopori suatu gerakan sosial, Sneevlietsudah diasingkan ke negeri asalnya Belanda oleh pemerintah Hindia-Belanda karena aktivitasnya yang dianggap telah mengganggu keamanan dan ketertiban di HindiaBelanda (Saleh, et al., 2009: 20). Walau demikian, Sneevlietsebelumnya telah mengkader tokoh-tokoh pribumi. Tokoh tersebut adalah Semaoen dan Darsono yang kemudian mengambil alih kepemimpinan ISDV menggantikan Sneevliet dan kemeraderopanya (Hasan, 2014: 9). hubungan dengan topik yang diangkat Sejak saat itu para tokoh pribumi yang dalam penelitian (Wiratha, 2006: 150). dipengaruhi ide-ide marxis menjadi lebih militan dan mandiri dalam mengorganisir massa (tidak tergantung dengan bangsa eropa).

Kondisi perekonomian di Hindia-Belanda yang tidak stabil sejak awal Perang Dunia I ataupun gejolak ekonomi yang terjadi pasca berakhirnya Perang Dunia I hingga tahun 1927, dimanfaatkan oleh golongan komunis untuk melancarkan dilakukan oleh serikat-serikat buruh, petani, dan pegawai negeri sipil (Hasan, 2014: 10). Puncak dari gerakan PKI pada saat itu terjadi pada tahun 1926-1927 yang berujung gagal dan mengakibatkan kehancuran PKI. Tujuan penelitian ini adalah ingin mencari penyebab mengapa pemberontakan PKI, khususnya pada puncak pemberontakan yakni 19261927 mengalami kegagalan. Kesimpulan sementara yang dapat diambil adalah Partai Komunis Indonesia (PKI) tidak memiliki sumberdaya yang mapan untuk melakukan gerakan pemberontakan kala itu. Sehingga menyebabkan kegagalan yang berujung diasingkan dan dieksekusinyasebagian besar tokoh komunis, serta pemberlakuan pelarangan segala aktivitas PKI dan serikat-serikat yang berkaitan dengannya.

\section{METODE PENELITIAN}

Penelitian ini menggunakan metode deskriptif. Sumber informasi berfokus pada penggunaan literatur dari beragam sumber, baik buku, jurnal, atau majalah yang memiliki Penelitian ini menggunakan teori dari David Locher tentang faktor-faktor dan mendukung gerakan-gerakan yang 
penentu keberhasilan dan kegagalan dalam gerakan sosial.

\section{HASIL DAN PEMBAHASAN}

\section{A. Partai Komunis Indonesia (PKI) Sebagai Gerakan Sosial}

Karena ruang lingkup gerakan sosial beragam, maka gerakan sosial memiliki definisi yang luas. Anthony Giddens mengemukakan bahwa gerakan sosial adalah upaya kolektif untuk mencapai kepentingan atau tujuan bersama di luar lingkup lembaga yang mapan melalui tindakan kolektif (Putra, et al., 2006: 1). Kemudian definisi lainnya dari gerakan sosial menurut Tarrow lebih diutamakan pada gerakan sosial sebagai gerakan perlawanan politik, yaitu gerakan rakyat biasa yang bersatu dengan orang-orang yang lebih berpengaruh untuk mengerahkan kekuatan melawan elit, penguasa, dan lainnya. Ketika perlawanan semacam ini didukung oleh jaringan sosial yang kuat dan dipromosikan oleh resonansi budaya dan simbol tindakan, politik perlawanan akan mengarah pada interaksi terus-menerus dengan lawan, dan hasilnya adalah gerakan sosial (Putra,et al., 2006: 1).

Menurut definisi Basrowi dan Sukidin(2003: 17), disebutkan bahwa gerakan sosial adalah salah satu media yang dapat menyampaikan ketidakpuasan sosial kepada pihak penguasa. Selain itu, menurutnya, gerakan sosial lahir dari kelompok yang terorganisir dengan prinsip dan tujuan yang jelas, pengaruh yang luas, dan ideologi baru, sehingga dapat berpartisipasi dalam penciptaan masyarakat. Secara teori gerakan sosial adalah gerakan yang diprakarsai oleh masyarakat untuk menuntut adanya perubahan kelembagaan, kebijakan, atau struktur pemerintahan. Di sini terlihat bahwa kebutuhan akan perubahan biasanya karena kebijakan pemerintah tidak lagi sesuai dengan latar belakang sosial yang ada, atau kebijakan tersebut bertentangan dengan keinginan sebagian orang (Sudarsono, 1976: 24-25).Sementara itu, menurut definisi Robert Misel dalam bukunya "Theory of Social Movement", gerakan sosial mengacu pada sekelompok keyakinan dan tindakan non-institusional yang dilakukan oleh sekelompok orang untuk mendorong atau menghalangi perubahan sosial (Misel, 2004: 6-7).

Dari hasil penjelasan di atas, maka gerakan sosial dapat diidentifikasi sebagai: (1) tindakan pertentangan/perlawanan terhadap elite, otoritas, dan terhadap aturan kelompok dan budaya lainnya; (2) suatu tindakan yang dilakukan atas dasar klaim yang sama terhadap pihak lawan, pihak berwenang, ataupun elite; (3) suatu tindakan yang di dasarkan atas ras solidaritas dan identitas kolektif; dan (4) dengan meneruskan tujuan tindakan kolektif, maka bentuk pertarungan diubah ke dalam suatu gerakan sosial.

Dengan demikian, sejak berdirinya ISDV yang merupakan cikal-bakal lahirnya PKI, para tokoh dalam organisasi ini membawa semangat kemerdekaan dan perlawanan pada Pemerintah Kolonial Hindia-Belanda. Hal tersebut merupakan respons dari bangsa Indonesia yang selama ini ditindas oleh Pemerintah Kolonial. Sejak datangnya Sneevliet pada tahun 1913, yang diikuti oleh tokoh marxis lainnya, seperti JA. Brandstender, Ir. A. Baars, Dr. Rinkes, C. Hartogh, P. Bergsma, dan lainnya, 
pertentangan kelas antara penjajah yang dilakukan oleh buruh pegadaian (Belanda) dengan bangsa terjajah yang menolak perlakuan sewenang(Indonesia) serta pertentangan antara wenang dari pegawai atasan golongan pemilik kebun (umumnya dijabat oleh orang Belanda) (borjuis/pemilik modal) dengan para dalam memberi perintah pegawainya pekerjanya (buruh) sudah lama dan untuk melakukan apa yang bukan sedang terjadi di mana-mana (Hasan, menjadi pekerjaannya, pemogokan di 2014, 7). Misalnya, keputusan Semarang, Madiun dan Surabaya pemerintah kolonial untuk menimbun kerena penangkapan yang dilakukan bahan makanan pokok dan oleh pemerintah kolonial kepada tokoh mengurangi hasil-hasil perkebunan pemimpin buruh Semaoenpada tahun sampai batas minimum sejak 1914-1927 1923 dan lain sebagainya (Lembaga dan mengharuskan rakyat Indonesia Sejarah PKI, 1961).

untuk memfokuskan menghasilkan bahan makanan sendiri yang mengakibatkan harga bahan pokok nasional melangbung, menaikan pajak yang dilakukan oleh Gubernur Fock pada tahun 1921 yang semakin memeras pribumi, PHK dan pemotongan upah, dan lain sebagainya (Hasan, 2014: 9-10).

Karena hal tersebut, membuat terbentuknya sebuah rasa solidaritas dalam masyarakat Indonesia dan melakukan gerakan aksi perlawanan untuk menentang kebijakan pemerintah kolonial hingga tahun 1927 (Niel, 1960: 247-248).Dalam situasi tersebut, tokoh-tokoh komunis berupaya mendukung dan mempelopori gerakan yang dilakukan oleh serikat-serikat buruh, petani, dan pegawai sipil. Aksi-aksi tersebut berupa pemogokan serentak dan penentangan terhadap kebijakan ekonomi pemerintah Hindia-Belanda dengan tujuan menuntut kesejahteraan rakyat (Hasan, 2014: 10). Misalnya aksi pemogokan pada bulan Agustus 1921 yang dilakukan oleh buruh pelabuhan di Semarang sebagai bentuk perlawanan kepada para majikan yang hendak menurunkan upah buruh, pada 11 Januari 1922 terjadi pemogokan

\section{B. Sejarah Kelahiran dan Eksistensi Partai Komunis Indonesia (PKI)}

Secara historis, ideologi komunisme pertama kali diperkenalkan di Nusantara pada tahun 1913 oleh Hendricus Josephus Franciscus Maria Sneevliet (Syukur, 2008: 1). Sneevlietadalah mantan ketua Sekretariat Buruh Nasional Belanda dan mantan pemimpin Partai Revolusi Sosialis di salah satu provinsi Belanda. Awalnya, Sneevliet bekerja di Surabaya sebagai editor buletin perdagangan SoerabajascheHandelsblad di East Java Sugar Group (Hasan, 2014: 7). Tak lama kemudian, dia pindah ke Semarang untuk bekerja sebagai sekretaris sebuah perusahaan dagang (Saleh, et al., 2009: 19).

Kota Semarang kala itu menjadi pusat organisasi pekerja kereta api Vereeniging van Spoor enTramwegPersoneel (VSTP) yang berdiri pada tahun 1908. Pada tahun 1914, VSTP membutuhkan propagandis untuk menyebarkan ideide yang diadopsi oleh organisasi tersebut. Sneevliet memanfaatkan kesempatan ini. Dia diangkat sebagai propagandisberbayar. Dengan cara ini, Sneevliet mengenal massa pekerja dan 
menyebarkan gagasan konfrontasi kelas. Pada Juli 1914, Sneevliet dan P. Bersgma, JA Brandstead (HW), Dekker (Sekretaris VSTP) mendirikan organisasi politik radikal, Indische Social Democratische Vereeniging(ISDV) atau Sosial Demokrasi India. ISDV kemudian menerbitkan surat kabar Het VrijeWoord (Suara Kebebasan). Terbitan pertama surat kabar itu tercatat pada 10 Oktober 1915. Sneevliet dan temantemannya menggunakan kabarHet menyebarkan VrijeWoord surat Marx.

Karena anggota ISDV terbatas pada orang Belanda, maka organisasi tersebut belum dapat menjalin dan mempengaruhi organisasi pergerakan nasional seperti BoediOetomo dan Sarekat Islam (SI). Upaya ISDV untuk mendekati masyarakat juga gagal karena ISDV tidak mendapat dukungan dari masyarakat. Namun kemudian, ISDV bersentuhan dengan Sarekat Islam (SI) yang dipimpin oleh Oemar Said Tjokroaminotomelalui sebuah organisasi buruh di Semarang. SI adalah organisasi politik berbasis nasionalisme Islam yang bercirikan anti kolonialisme dan kapitalisme asing. Sneevliet dan kawan-kawan perlahan mengikuti dengan seksama karakteristik dan aktivitas Sarekat Islam. Mereka berniat memanfaatkan sentimen anti-kolonial dan kapitalis asing pengikut SI.

Setelah Revolusi Oktober di Uni Soviet yang dipimpin oleh Lenin pada 1917, sifat gerakan ISDV menjadi semakin radikal dan secara terangterangan mengaku komunisme. Para pemimpin ISDV perlahan mendekati dan mempengaruhi para pemimpin Sarekat Islam di Semarang dengan ideide revolusioner model Rusia, yang juga anggota VSTP. Selain itu, para pemimpin ISDV melakukan propaganda di dalam angkatan bersenjata. KhusunyaSneevliet, salah satu tokoh yang berperan untuk mempengaruhi Angkatan Darat dan Angkatan Laut. Sementara, Brandstedder juga mendekati tentara Angkatan Laut, dan Bar serta van Burink mendekati pegawai negeri. Sneevliet melakukan berbagai kegiatan, ceramah, dan kursus politik. Karena dorongannya, Raad van Mat frozen enMariniers (Dewan Kelasi dan Marinir) didirikan, sebuah organisasi yang radikal dan revolusioner di antara anggota militernya. Kegiatan Sneevliet sepenuhnya dibantu oleh Brandstedder, yakni kepala Soerabajasche Marine Gebouw (Balai Angkatan Laut Surabaya) dan editor surat kabar Soldateenen Matt frozenkrant (surat kabar Serdadu dan Kelasi). Ratarata, isi surat kabar yang diterbitkan adalah gagasan-gagasan komunis revolusioner dan gagasan-gagasan perjuangan kelas.

Pemerintah Hindia Belanda kemudian mengambil tindakan tegas. Pada Desember 1918, Sneevliet diusir dari Hindia Belanda karena aktivitasnya yang dianggap mengganggu keamanan dan ketertiban. Setelah itu, pada September 1919, Brandstedder pun menyusul Sneevliet. Walaupun Sneevliet dan Brandstedder telah meninggalkan Hindia Belanda (Indonesia), namun sebelumnya mereka sudah berhasil memberikan pengaruh di Angkatan Laut Surabaya, setidaknya mereka telah membentuk organisasi yang bertumpu pada Partai Komunis. Sementara di lingkungan Sarekat Islam, ISDV juga telah berhasil mempengaruhi pimpinan SI Semarang 
yakni,Semaoen dan Darsono yang juga merupakan anggota VSTP. Setelah berhasil mendapatkan tempat di Gedung Sarekat Islam Semarang pada tanggal 23 Mei 1920, ISDV berganti nama menjadi Perserikatan Komunis di Indie (PKI). Semaoen terpilih sebagai ketua dan Darsono terpilih sebagai wakil ketua. Beberapa tokoh ISDV di Belanda diangkat menjadi mentor, antara lain Bersgma sebagai sekretaris, Dekker sebagai bendahara dan A. Baars sebagai anggota. Pada tahun itu juga Perserikatan Komunis di Indie berganti nama menjadi Partai Komunis Indonesia (PKI) dan memiliki surat kabarSoearaRa'jat. Sekalipun Semaoen dan Darsono menjadi pimpinan PKI, namun mereka tetap menjadi ketua Sarekat Islam Semarang, dan juga memimpin organisasi (media massa) SI, Sinar Hindia. Kegiatan SI Semarang dan PKI berjalan seiring, SI Semarang mendirikan sekolah SI, tetapi mengajarkan siswa lagu-lagu internasionale, yaitu mars komunis.

Tokoh komunis terus menyusupi doktrin-doktrin komunis dengan cara menumpang pada pertemuan-pertemuan SI untuk menyebarkan pengaruhnya. Pada awalnya kegiatan SI yang diselenggarakan oleh PKI masih diperbolehkan oleh Sarekat Islam Pusat (CSI), karena anggota SI diperbolehkan menjadi anggota organisasi lain sesuai dengan peraturan organisasi SI. $\begin{array}{lll}\text { Dengan kata lain, SI tidak melarang } \\ \text { keanggotaan } & \text { ganda. }\end{array}$

PKI memanfaatkan sistem keanggotaan ganda ini untuk membagi SI secara internal. Dalam dunia komunis, memisahkan organisasi dari organisasi adalah strategi blok internal atau aksi internal (block within). Strategi blok internal dicapai dengan menyuntikkan kader atau anggota komunis untuk menjadi anggota organisasi sasaran. Kemudian mereka mencoba memengaruhi atau memecah belah organisasi. Taktik atau strategi ini diterapkan pertama kali pada organisasi SI yang merupakan salah satu organisasi terbesar kala itu.

Pada saat yang sama, persaingan antara SI dan PKI yang didirikan pada tahun 1920 semakin sengit, terutama dalam merebut pengaruh organisasi buruh. Pada Desember 1919, atas prakarsa tokohtokoh Sarekat Islam, dibentuklah serikat organisasi buruh yang disebut Persatuan Pergerakan Kaum Buruh (PPKB) yang diketuai oleh Pimpinan SI Semarang sekaligus Ketua VSTP yakniSemaoen, Suryopranoto sebagai wakil ketua, dan Agus Salim menjabat sebagai sekretaris. PPKB adalah federasi dari 22 organisasi buruh dengan 27.000 anggota. Kegiatan organisasi yang paling utama adalah untuk melancarkan pemogokan pekerja dengan tujuan memperjuangkan kepentingan buruh dan melawan undang-undang ketenagakerjaan kolonial yang buruk. Pada Kongres II (Juni 1921),sarekat pekerja PPKB di Yogyakarta mengalami perpecahan. Semaoen dan Bergsma dan 14 SarekatSerja memisahkan diri dan mendirikan Revolutionnair-SocialistischeVakcentrale, yang dipimpin oleh VSTP pada Juni 1921. Sementara Surjopranoto dan Agus Salim berhasil melindungi serikat buruh lainnya dari doktrin atau pengaruh komunis (Saleh, et al., 2009: 19).

Dalam waktu 4 tahun (Mei 1920 hingga Desember 1924) PKI berhasil 
berkembang menjadi organisasi yang sangat kuat dan sekaligus mengancam pendudukan pemerintah Kolonial Hindia-Belanda. Dengan demikian, pemerintah Hindia Belanda terus melakukan upaya pengawasan secara ketat, walaupun tidak ada dampak yang signifikan terhadap perkembangan PKI.

\section{Kegagalan Pemberontakan Partai Komunis Indonesia (PKI)}

Terdapat beberapa faktor yang menentukan keberhasilan atau kegagalan suatu gerakan sosial. Menurut Locher dalam Sukmana (2016: 33) faktor-faktor tersebut antara lain: kepemimpinan, citra, taktik, tujuan, dan dukungan.Dalam konteks kegagalan pemberontakan PKI 19261927, maka dapat dianalisis sebagai berikut:

1. Aspek Kepemimpinan Gerakan Pemberontakan PKI 1926-1927

Salah satu syarat yang menentukan apakah suatu gerakan itu berhasil atau tidak adalah kepemimpinan. Dalam konteks ini, suatu gerakan harus memiliki kepemimpinan yang efektif (effective leaders), yaitu individu yang dapat memahami sistem hukum dan politik di tempat gerakan sosial dilakukan (Sukmana, 2016: 33-34). Para pemimpin dalam suatu gerakan sosial harus menfokuskan perhatian kepada tugastugas yang diperlukan untuk mencapai tujuan kelompok. Mereka mengartikan yang kemudian dijelaskan kepada pihak-pihak eksternal kelompok tentang rasionalitas dan tujuan kelompok. Dan suatu hal yang terpenting adalah para pemimpin harus memiliki kemampuan untuk dapat memberikan inspirasi kepada orang lain agar bertindak dan mengikuti suatu gerakan sosial, serta mengkoordinir massaagar melakukan sesuatu sesuai arahan/apa yang direncanakan.

Dalam konteks ini, sejak diasingkannya para tokoh pemimpin PKI ke luar Hindia-Belanda, seperti Sneevlietdan kawan-kawan Eropa lainnya pada tahun 1919, dilanjutkan ketua dan wakil PKI selanjutnya: Semaoen dan Darsono pada tahun 1921 (walau dapat menyusup kembali ke Indonesia pada tahun 1922, tapi kemudian diasingkan kembali pada 18 Agustus 1923 ke Belanda dan Darsono pada 1925), kemudian Tan Malaka pada tahun 1922, sementara tokohtokoh lain seperti Alimin, Muso, dan Sardjono melarikan diri ke Singapura, tentu saja hal ini memiliki dampak bagi perkembangan PKI (Hasan, 2014: 10).

Pada tanggal 11-17 Desember 1924 PKI mengadakan kongres di Yogyakarta yang dihadiri 38 cabang PKI yang mewakili 1.237 anggota PKI dan 46 SarekatRakjat yang mewakili 33.748 anggota SR menghasilkan keputusan untuk memperkuat barisan pergerakan (melakukan persiapanuntuk revolusi yang bertujuan untuk mengadakan aksi perlawanan terhadap pemerintah kolonial Belanda pada tahun 1926) (Pringgodigdo, 1991: 36). Keputusan tersebut diambil karena pengurus besar PKI (Sarjono, Budi Sucitro, Alimin dan beberapa pengurus lainnya) merasa keadaan semakin genting akibat tekanan yang dilakukan oleh pemerintah kolonial terhadap mereka. Namun Tan Malaka yang sedang berada di Cina menolak keputusan tersebut bahkan meminta keputusan itu untuk di cabut karena dinilai dari segi organisasi maupun 
rencana dirasa belum matang (Hasan, 2014: 11).

Beberapa bulan setelah kongres itu dilaksanakan, Alimin dan Muso pergi ke Rusia untuk menemui pimpinan pusat komintern, akibatnya pemimpin PKI yang berada di Indonesia mengalami kepanikan. Ketika dorongan untuk melakukan aksi dari rakyat semakin kuat yang telah mengalami rasa penderitaan akibat depresi ekonomi dan kerusuhan, selain itu hilangnya sebagian besar pemimpin PKI yang berpengalaman dan bersifat moderat menyebabkan PKI berada ditangan kaum muda yang cenderung berpikir panas. Tokoh-tokoh kaum muda PKI itu diantaranya Dahlan, Sukrawinata, Baharudin Saleh, Mahmudi dan Abu Bakar. Selama satu setengah tahun setelah kongres besar di Yogyakarta, PKI semakin dipengaruhi oleh dorongan-dorongan anarkis. Sehingga saat itu PKI lebih mengikuti naluri memberontak dari pada mempertimbangkan kekuatan yang dimiliki (Wild, 1986:31).

Di akhir tahun 1926 tanpa koordinasi dengan pimpinan yang sedang berada di pengasingan PKI mulai melakukan aksi, (12-14 November 1926 di Jakarta, Jatinegara, dan Tanggerang, 12-15 desember 1926 di Keresidenan Banten, 12-18 November 1926 di Priangan; 17-23 November 1926 di daerah Solo, 12-15 Desember 1926 di Kediri), aksi-aksi itu dapat terjadi dikarenakan tidak adanya Semaoen dan Darsono yang selalu menghalangi terjadinya revolusi yang dianggap prematur dan terlalu cepat (Hasan, 2014: 12). Pemerintah Hindia Belanda menanggapi gerakan tersebut dengan mengambil tindakan tegas, tanggal 1 Desember 1926 sebanyak 106 pemegang karcis merah dari Tanah Abang dan karet digiring ke kantor Kabupaten Molenvliet daerah Weltevreden (Gambir). Sementara pimpinan pusat PKI melarikan diri ke Rusia.

Sedangkan di Surakarta, pada bulan-bulan terakhir 1925 telah memperlihatkan kehancuran PKI dan SarekatRakjat (SR) di bawah pimpinan Marco (Shiraishi, 2005: 448). Sejumlah besar anggota PKI merasa tidak puas dengan Marco, para hoofdbestuur/pengurus pusat PKI, dan SR karena hanya sekadar berbicara tanpa ada aksi langsung. Akibatnya para anggota yang memiliki militansi tinggi bertindak nekad dengan menuliskan artikel di Medan Moeslimin yang isinya menyerukan untuk mengorganisir aksi revolusioner (Shiraishi, 2005: 450).Akibat artikel tersebut pimpinan partai (baik pusat atau seksi) tidak dapat menahan anggota PKI dan SR dari tindakan nekad mereka untuk menjalankan aksiaksinya secara sendiri-sendiri.

Pada akhir September 1925, pada acara perayaan Sekaten, bombom dilemparkan, perampokan, dan pencurian berserta pembakaran rumah terjadi, beberapa anggota SR ditangkap. Akibatnya pemerintah semakin memperketat pengawas terhadap PKI dan menolak hak berkumpul baik PKI atau semua serikat yang berafiliasi dengan PKI (SR, SBG, VSTP, SBB) pada bulan Desember (Shiraishi, 2005: 450). Marco sebagai ketua PKI dan SR Surakarta mencoba melakukan berbagai usaha untuk mempertahankan organisasi tersebut, misalnya menyusun pembagian kerja baru antara serikat-serikat di bawah pimpinan PKI.Namun tindakan itu 
terbukti sia-sia dan pergerakan PKI di daerah-daerah satu-persatu menemui ajalanya pada tahun 1926-1927.

\section{Aspek Citra Partai Komunis Indonesia (PKI)}

Keberhasilan suatu gerakan terjadi apabila dihargai dan dihormati oleh orang lain. Suatu gerakan mencoba meyakinkan semua pihak termasuk serikat-serikat, organiasiorganisasi dan pemegang otoritas bahwa mereka memiliki tujuan yang baik bagi kehidupan masyarakat (Sukmana, 2016: 34). Citra publik terhadap suatu kelompok atau golongan juga tidak kalah penting, tujuannya adalah untuk mendapat dukungan dari semua elemen masyarakat. Artinya organisasi atau kelompok yang mempelopori suatu gerakan sosial harus menciptakan image positif agar suatu gerakan dapat berhasil.

Sedangkan PKI sering kali mengalami konflik dengan tokohtokoh pergerakan, organisasi, terutama organisasi keagamaan. Misalnya, pertentangan ideologis antara Islamisme Partij Sarekat Islam (CSI/PSI) dan komunisme PKI/SI Merah, yang mengakibatkan organisasi SI terpecah menjadi dua kubu yakni SI Putih kelompok Tjokroaminoto dan Agus Salim dan SI Merah kelompok Semaoen dan Darsono yang diwakili SI cabang Semarang. Ketika kongres di Madiun pada tahun 1923 Agus Salim mengatakan bahwa PKI dapat membahayakan kesatuan Islam dan Tjokro berpendapat bahwa SI mempercayakan segala sesuatu pada Allah, sementara PKI tidak. Setelah kongres itu, Semaoen menyerang balik pimpinan CSI dan Tjokro, dan menganggap CSI tengah di bawah pengaruh kapital (uang), sementara bagi $\mathrm{H}$. Misbach (propagandis SI Merah/PKI) Tjokro adalah racun (Siraishi, 2005: 327-329). Golongan PKI kerap mengkritik SI sebagai pelindung kepentingan kapital para feodal/kaum priayi pribumi. Bagi golongan PKI, SI dibangun atas kelompok-kelompok pedagang Islam dan kaum industial, dan bukan oleh rakyat.

Sikap kelompok PKI yang cenderung radikal dan tanpa tawarmenawar sangat tidak disukai pemerintah. PKI dianggap sebagai partai yang menjadi ancaman terhadap status quo pemerintah karena semangat komunismenya, apalagi partai tersebut secara terang-terangan pada bulan Desember 1924 berkeinginan untuk merebut kekuasaan (McVey, 2006: 293). Oleh karena itu, pemerintah kolonial sejak dipimpin oleh Fock pada tahun 1924 mengadakan langkah pencegahan untuk mengontrol golongan komunis misalnya dengan mempersiapkan tindakan hukum, kepolisian, dan administratif (Siraishi, 2005: 428). Wakil pemerintah kolonial memerintahkan penguasa lokal untuk lebih memperketat pada pertemuanpertemuan golongan komunis. Mereka yang berumur di bawah 18 tahun dilarang mengikuti pertemuan, dan apabila seseorang membicarakan sesuatu yang meresahkan maka pertemuan tidak jarang langsung dibubarkan. Di sisi lain, para tokoh komunis juga banyak yang ditangkap oleh pemerintah atas tuduhan pelanggaran terhadap pernyataan di depan umum (speekdelicten), bahkan di beberapa daerah misalnya Madiun dan Priangan, vergadering (rapat umum) dengan paksa dibubarkan oleh polisi. 
Karena sikap dan pemikirannya, golongan komunis sama sekali tidak dekat dengan kelompokkelompok pejabat Belanda (Siraishi, 2005: 299-300). Berbeda dengan tokohtokoh SI Putih seperti H. Agus Salim yang dekat dengan kaum etisi Belanda, misalnya menjadi murid dari $C$. SnouckHurgronje (penasihat untuk urusan bumiputera pertama), punya pengalam bekerja sebagai staf Volkslectuur (Komisi untuk Bacaan Rakyat) pimpinan Dr. Rinkes, satusatunya orang anggota SI yang ditunjuk untuk masuk dalam komisi CerpenterAlting untuk mereformasi konstitusional negara Hindia, dan punya akses terhadap birokrat tinggi Belanda seperti W. Muurling, mantan kepala Dinas Intelijen Politik (PID) dan wakil pemerintah dalam Volkstraad (Dewan Hindia Belanda), D. Talma, direktur keuangan dan ketua Sindikat Gula dan R.A. Kern, wakil Penasihat Urusan Bumiputera menggantikan Hazeu pada tahun 1920.

Dengan demikian, PKI hanya hanya disukai oleh kelompokkelompok buruh, petani, dan para pegawai (kalangan kelas bawah). Sementara dengan sebagian besar golongan keagamaan tidak memiliki hubungan yang baik, dan bahkan saling menjatuhkan. Akibat perpecahan tersebut, gerakan nasional otomatis melemah. Apalagi PKI tidak memiliki relasi dengan pejabat pemerintahan Hindia-Belanda, sehingga gerakan yang diinisasi PKItidak didukung misalnya dariaspek kebijakan, moral, atau material. Pemerintah dalam hal ini malah bersikap sebaliknya, yaitu menumpas gerakan tersebut.
3. Aspek Taktik Pada Gerakan Pemberontakan PKI 1927-1927

Suatu gerakan akan berhasil jika terdapat taktik di dalamnya. Suatu gerakan hanya akan berhasil jika menggunakan taktik-taktik yang dapat diterima secara sosial (Sukmana, 2014: 34). Taktik atau strategi yang dipilih harus dapat meyakini massa gerakan dan efektif digunakan untuk mencapai tujuan gerakan. Dengan demikian, situasi Socially Accepted Tactics memiliki pengaruh terhadap pembentukan rasa hormat dan citra positif dari publik.

Pada konferensi PKI di Kota Gede, Yogyakarta (1924),hoofdbestuurPKI yang baru terbentuk, Sardjono (ketua), Boedisoetjitro (sekretaris), Winata (bendahara), Alimin dan Aliarcham (komisaris) membentuk komite eksekutif. Sementara Soewarno dari PKI Surakarta terpilih sebagai komisaris yang mewakili seksi PKI di daerah-daerah.Saat itu Aliarcham menyampaikan usulan-usulan hoofdbestuur PKI untuk menghapuskan SR yang borjuis kecil, memperluas sekaligus mendisiplinkan PKI melalui pembentukan sel-sel berdasarkan sistem yang berjumlah 10 orang-an, dan mengintensifkan usaha mengorganisir buruh ke dalam serikat buruh yang revolusioner. Tapi usulan pembubaran SR tersebut ditentang oleh Darsono dan para pemimpin PKI cabang Semarang lainnya, dengan alasan bahwa SR masih diperlukan. Perintah untuk membentuk sel-sel juga tidak dilaksanakan. Hanya satu perintah yang dilaksanakan, yaitu untuk mendorong anggota SR untuk bergabung dengan PKI sebagai calon anggota, akibatnya jumlah anggota biasa PKI membengkak, dan akhirnya 
peralihan tersebut (partai kader)
menghasilkan partai massa yang tidak disiplin (Shiraishi, 2005: 433-435).

Ketika rencana PKI tersebut gagal, di sisi lain PKI juga melakukan usaha untuk mengorganisir buruh ke dalam serikat buruh yang revolusioner. Pada tahun 1925 ketika serikat buruh telah terbentukpara buruh yang terlanjur tidak puas kemudian mendesak pimpinan serikat untuk melakukan aksi dan melancarkan pemogokan liar. Sejak pertengahan 1925 buruh-buruh terus mogok, namun pemerintah kolonial telah menyiapkan pasal, buruh-buruh yang mogok kemudian dipecat dan hak berkumpul dicabut kembali.

Para propagandis/pemimpin-pemimpin serikat buruh ditangkap dan pada akhir 1925 pemogokan-pemogokan berakhir dan serikat-serikat buruh sebagian besar hancur (Shiraishi, 2005: 435). Para pemimpin pusat PKI juga dibuang di antaranya Aliarcham (komisaris), Mardjohan (komisaris), dan Darsono.

Pada bulan November dan Desember pemerintah menarik hak berkumpul PKI, SR, VSTP, dan semua serikat-serikat yang berhubungan dengan PKI. Karena aksi pemogokan tersebut, pemerintah kolonial semakin tegas. Pada Mei 1926 pemerintah kolonial mengeluarkan pasal 153bis, yang mana pasal ini menghukum dengan berat bagi siapa saja dengan sengaja mengekspresikan baik dengan kata-kata maupun tulisan, atau gambar yang menuju ke usaha mengganggu ketentraman umum, menggulingkan, atau mengintervensi kekuasaan di Hindia Belanda, atau mereka yang menciptakan suatu lingkungan yang memiliki peluang untuk munculnya keadaan tersebut serta bagi mereka yang menyebarkan, mempertunjukkan, atau menerbitkan untuk maksud tersebut (Shiraishi, 2005: 436). Dengan demikian empat bentuk utama pergerakan PKI (mogok, rapat, rapat anggota, dan surat kabar) tidak bisa lagi digunakan. Dalam hal ini, PKI gagal membentuk suatu strategi yang mapan dan diterima oleh seluruh anggota.

\section{Aspek Tujuan Pada Gerakan Pemberontakan PKI 1926-1927}

Suatu gerakan yang berhasil memerlukan pandangan pihak luar bahwa suatu gerakan sosial tersebut memiliki tujuan yang baik dan untuk kepentingan masyarakat, bukan untuk merugikan kepentingan mereka. Para tokoh gerakan harus bisa meyakinkan pihak pengamat (bystanders) bahwa jika suatu gerakan berhasil maka mereka akan mendapatkan/merasakan apa yang sebelumnya diperjuangkan. Dengan demikian, maka akan menjaga pengamat (bystanders) yang memiliki peluang untuk berubah dan masuk menjadi lawan (opponents) gerakan sosial tidak melakukannya. Selain itu, kita harus bisa menyakinkan para pengamat tersebut bahwa mereka memiliki kepentingan dan keuntungan yang positif jika suatu gerakan itu berhasil. Semakin dekat tujuan suatu gerakan dengan ideologi atau kultur masyarakat, maka gerakan tersebut memiliki peluang yang besar untuk mendapat dukungan publik dan berhasil.

Tujuan PKI saat itu adalah untuk membentuk masyarakat sosialis di Indonesia (Lembaga Sejarah PKI, 1961: 103). Saat itu PKI beranggapan bahwa sifat masyarakat Indonesia memiki kesamaan dengan masyarakat di negeri kapitalis atau paling tidak 
dianggap sama dengan masyarakat Uni Soviet (Rusia) sebelum revolusi (Lembaga Sejarah PKI, 1961: 104). Tentu anggapan ini keliru, karena kondisi masyarakat Indonesia saat itu ialah masyarakat jajahan dan setengah feodal (Lembaga Sejarah PKI, 1961: 104). Akibat kesalahan mendasar tersebut, maka otomatis PKI juga salah dalam melihat watak revolusinya, kekuatan penggeraknya, dan siapa yang dianggap sekutu.

Penentuan sosialisme sebagai basis program urgensi dan semboyan dalam melakukan aksi sudah pasti salah dalam menentukan musuhnya, yaitu bahwa golongan kapitalis yang dijadikan sebagai sasaran revolusi, sementara tidak membedakan antara kapitalis monopoli dan kapitalis nasional/kapitalis yang kapitalnya tidak ditransfer ke luar negeri (domestic capital) (Lembaga Sejarah PKI, 1961: 104). Artinya, PKI tidak melihat kedudukan ekonomi dari kaum kapitalis nasional di dalam kekuasaan kapitalis monopoli, tidak melihat bahwa kapitalis nasional dirugikan oleh kapitalis monopoli, dan akibatnya juga PKI tidak dapat melihat watak revolusioner dari kelompok kapitalis nasional dalam memperjuangkan kemerdekaan nasional. Oleh karenanyaPKI tidak memiliki front persatuan terhadap semua lapisan atau kekuatan yang mendasarkan pada antiimperialis dan anti-feodal.

Karena semboyan Sosialisme dengan mengacu pada Soviet sebagai instrumen revolusi sosialis saat itu, berarti menyisihkan lapisan, kekuatan anti-imperialis yang bukan kelas buruh, dan bukan kaum pekerja lainnya.Menurut Stalin, cara tersebut adalah sebuah bentuk penyelewengan dalam gerakan revolusi dan akan membahayakan PKI itu sendiri karena telah memisahkan Partai dari massa dan mengubahnya menjadi sekte (Lembaga Sejarah PKI, 1961: 104-105). Hal tersebut sangat tidak sejalan dengan Sosialisme-Ilmiahnya Marx dan Engels bahwa kaum komunis yang memimpin revolusi harus menggalang persatuan dengan semua golongan dan lapisan sesuai dengan tingkat revolusinya.

Walaupun PKI sempat melakukan kerjasama dengan pimpinan gerakan nasional dari elemen borjuasiseperiTjokroaminoto, Tjipo Mangunkusumo, dan lainnya. Tetapi kerjasama tersebut tidak didasarkan pada pengertian Marxis-Leninis mengenai watak masyarakat Indonesia dan kekuatan pendoronganya (Lembaga Sejarah PKI, 1961: 105). Akibatnya kerjasama itu akan tidak kokoh dan berakhir pada pecahnya persatuan karena perbedaan tujuan.

\section{Aspek Dukungan Pada Gerakan Pemberontakan PKI 1926-1927}

Sebagian besar kelompokkelompok gerakan sosial mendapatkan dukungan politik dan material (uang) dari jaringan kelompok, organisasi, dan intitusi yang lainnya. Suatu gerakan sosial yang berhasil, harus mengombinasikan pendekatan dan teknik persuasi dengan tujuan untuk mendapatkan dukungan politik maupun finansial (Sukmana, 2014: 3536). Sementara suatu gerakan sosial yang gagal terjadi akibat tindakan penyerangan secara tidak terukur kepada semua pihak termasuk pendukung potensial, baik politik maupun finansial. Sehingga sering kali 
menyebabkan terjadinya penguatan sebesar 4000 gulden (mata uang Hindia oposisi dan penarikan dukungan dari Belanda saat itu) dengan bunga kepada pihak partisipan. Namun hal tersebut pimpinan pusat Persatuan Pegawai tidak dilakukan oleh golongan PKI.

Pegadaian Bumiputra (PPPB);

Tokoh PKI Darsonosaat itu Menuduh Moehammadijah telah melakukan penyerangan terhadap meninggalkan PPPB saat hak tokoh pimpinan SI HOS Tjokroaminoto berkumpul dicabut dan ketika residen dan Brotosoehardjo dengan cara (provinsi) mengancam karena menuduh mereka telah memanfaatkan keikutsertaan mereka dalam dana SI untuk kepentingan pribadinya pemogokan; dan (3) Menuduh mereka (Shiraishi, 2005: 310). Sebelumnya lebih takut pada residen daripada tuduhan tersebut hanya digunakan Allah dan mundur dalam perjuangan sebagai taktik untuk mencegah melawan fitnah (Siraishi, 2005: 349).

hoofdbestuur CSI mengintrodusir

Tidak hanya Sismadi, beberapa gagasan pemurnian partai dalam tubuh redaktur dari Medan Moeslimindan SI, namun karena alasan itu pula Islam Bergerak, misalnya Koesen, hubungan antara SI dan PKI semakin Soerjosasmojo, Ahmad Dasoeki, dan tidak harmonis (Shiraishi, 2005: 311). Sjarief juga turut serta mengkritik Sehingga pada Kongres ke-6 SI Moehammadijah dengan alasan ingin diputuskan bahwa SI akan memurnikan tubuh Moehammadijah menerapkan disiplin partai, yakni dari segala noda yang ada. Karena hal memberlakukan larangan keanggotaan ituFachrodin kemudian keluar dari ganda yang memberikan pilihan Islam Bergerak dan Harsoloemekso kepada anggota yang didapati (redaktur Islam Bergerak sekaligus menjalankan keanggotaan ganda untuk sekertarisMoehammadijah cabang tetap menjadi anggota SI atau memilih Surakarta) mencoba meredam organisasi lain. Langkah ini dinilai serangan itu, dan hubunganPKI dan sebagai pembersihan terhadap Mohammadijahkemudian menjadi anggota-anggota PKI di tubuh SI, renggang.Tentu saja kritik itu akibatnya organisasi SI terpecah diperlukan, terutama karena mereka menjadi dua yaitu SI Putih dan SI bukan kelas pekerja namun kelas atas Merah.

Tidak hanya bertentangan (borjuis). Namun yang perlu diperhatikan, kritik tersebut harus dengan SI, PKI jugaberkonflik dengan dilakukan dengan cara yang tidak kelompok Moehammadijahatau golongan putih lainnya. Beberapa tokoh PKI kerap menyerang golongan berpotensi merusak persatuan yang pada akhirnya mengakibatkan melemahnya gerakan nasional.

Mohammadijah sebagai kelompok munafik. Misalnya SismadiSastrosiswojo (redaktur

\section{SIMPULAN}

Penggoegah milik SI-Merah) dan juga memberikan kesimpulan bahwa redaktur dari Islam Bergerak, kegagalan pemberontakan PKI 1926menyerang hoofbestuur 1927 terjadi karena; (1) Tidak adanya Moehammadijah dengan tiga isu: (1) pemimpin yang efektif yang Dengan mengatakan bahwa memahami politik dan hukum, atau Moehammadijah meminjamkan uang pemimpin yang dapat mengorganisir 
massa dengan baik; (2) Gerakan tersebut tidak memiliki citra yang baik di berbagai kalangan khususnya kelompok Sarekat Islam dan Mohammadijah atau golongan putih lainnya; (3) Gerakan tersebut tidak memiliki taktik atau strategi yang mapan dan baik sehingga tidak diterima oleh sebagian besar anggota; (4) Kesalahan dalam mengidentifikasi masalah yang berakibat kesalahan pada tujuan, watak revolusi, dan menentukan sekutu; dan (5) Tidak mendapat dukungan dari organisasi potensial akibat kesalahan dalam menentukan sekutu atau musuh.

\section{DAFTAR PUSTAKA}

Ahmad, A. (2017). Hak Menguasai Negara Di Bidang Ekonomi (Analisis Dalam Perspektif Komunisme). Kumpulan Jurnal Mahasiswa Fakultas Hukum.

As'ad, Saleh, dkk.(2009). Komunisme di Indonesia Jilid I. Jakarta: Pusjarah TNI.

Basrowi dan Sukidin. (2003). Teori-teori Perlawanan dan Kekerasan Kolektif. Surabaya: Penerbit Insan Cendikia.

Basrowi dan Sukidin. (2003). Teori-teori Perlawanan dan Kekerasan Kolektif. Surabaya: Penerbit Insan Cendikia

Budiardjo, Miriam. (2005). Dasar-dasar Ilmu Politik. Jakarta: Gramedia Pustaka Utama.

Della Porta, Donatella dan Mario Diani. (2006). Second Edition Social Movementan Introduction. United Kingdom: Blackwell Publishing.

Engels. Sosialisme Utopis dan Sosialisme Ilmiah. Diunduh di https://www.marxists.org/ indonesia/archive/marxengels/1880/uto ilmu/index.htmtanggal 3 Maret 2021.

Hirzan, A., \& Hasanuddin, H. (2017). Gerakan Masyarakat Dalam Membentuk Kenegerian Tiga Lorong Baturijal Hulu Sebagai Desa Adat di Kecamatan Peranap Kabupaten Indragiri Hulu Tahun 2014-2015 (Doctoral dissertation, Riau University). PhD Thesis. Riau University.

Hasan, Y. (2014). Indische Social DemocratischeVereniging (ISDV)
Merupakan Cikal Bakal Partai Komunis Indonesia (PKI). Jurnal Pendidikan dan Kajian Sejarah, 3(5), 6-13.

Juwono, Sudarsono. (1976). Pembangunan dan Perubahan Politik. Jakarta: Gramedia.

Klandersmans, Bert. Social Movements: Trends and Turns, in Stella Quah and Arnauld Sales (eds). The International Handbook of Sociology. London: Sage.

Locher David A. (2002). Collective Behavior. New Jersey: Prentice Hall.

Lembaga PKI Sejarah. (1961). Pemberontakan November 1926. Yayasan Pembaharuan: Jakarta.

McVey, R. T. (2006). The Rise of Indonesian Communism. Singapore: Equinox.

Misel, Robert. (2004). Teori Pergerakan Sosial. Yogyakarta: Resist Book.

Mandel, Ernest. Pengenalan Kepada Teori Ekonomi Marxis. Diunduh di https://www.marxi sts.org/indonesia/archive/mandel/002. htm. Diakses pada tanggal 3 Maret 2021.

Misel, Robert. (2004). Teori Pergerakan Sosial. Yogyakarta: Resist Buku.

Niel, Robert Van. (1960). The Emergence of Modern Indonesia Elite. Den Haag: N.V. Uilgeverij.

Pringgodigdo, A. K. (1991). Sejarah Pergerakan Rakyat Indonesia (Cet. 10).

Pichardo, Nelson A. 1997. New Social Movements: A Critical Review. Dalam Annual Review of Sociology; 1988; 23.

Putra, Fadillah. (2006). Gerakan Sosial. Malang. Averroes Press.

Saleh As'adDjamhari, dkk. (2009). Komunisme di Indonesia. Jakarta: Pusjarah TNI.

Shiraishi, Takashi. (1997). Zaman Bergerak; Radikalisme Rakyat di Jawa 1912-1926. Jakarta: Grafiti.

Sunarto, Kamanto. (2004). Pengantar Sosiologi (edisi ketiga). Jakarta: LembagaPenerbit Fakultas Ekonomi, Universitas Indonesia.

Sukmana, O. (2016). Konsep dan Teori Gerakan Sosial. Malang: Intrans Publishing.

Sudarsono, J. (1976). Pembangunan Politik dan Perubahan Politik. Jakarta: Gramedia.

Syukur, A. (2008). Kehancuran Golongan Komunis di Indonesia. Jurnal Sejarah Lontar, 5 (2), 1-8.

Wirartha, I Made. (2006). Metode Penelitian Sosial Ekonomi. Yogyakarta: Andi Offset. 
Politeia: Jurnal Ilmu Politik 14 (1) (2022): 1-17

Wild, C. (1986). Gelora Api Revolusi: Sebuah Antologi Sejarah. Jakarta: PT Gramedia. 